Reviu Akuntansi dan Bisnis Indonesia, Vol. 2 No. 1, Hlm: 51-63, Juli 2018

Website: http://journal.umy.ac.id/index.php/rab

\title{
Analisis Faktor-Faktor Yang Memengaruhi Intensi Pegawai Negeri Sipil (PNS) Untuk Melakukan Tindakan Whistleblowing : Studi Empiris pada Badan Pemeriksa Keuangan RI dan Pemerintah Kota serta Kabupaten di Daerah Istimewa Yogyakarta
}

\author{
Diah Hapsari Dianingsih; Suryo Pratolo \\ Program Studi Akuntansi Univeritas Muhammadiyah Yogyakarta
}

I N F O A R T I K E L

\section{Kata Kunci:}

Tingkat Keseriusan

Kecurangan, Self Efficacy,

Dukungan Organisasi,

Locus of Commitmentdan

Intensi untuk Melakukan

Tindakan Whistleblowing.

Jenis Artikel:

Penelitian Empiris

Correspondence:

diahapsaridianingsih@gmail.com

\begin{abstract}
A B S T R A K
Penelitian ini bertujuan untuk menguji secara empiris determinan whistleblowing yang terdiri dari tingkat keseriusan kecurangan, self efficacy, dukungan organisasi dan locus of commitmentsebagai variabel intervening. Populasi dalam penelitian ini yaitu Pegawai Negeri Sipil di lingkungan Badan Pemeriksa Keuangan Republik Indonesia perwakilan ProvinsiDaerah Istimewa Yogyakarta dan Pegawai Negeri Sipil di lingkungan Pemerintah Kota sertaKabupaten di Daerah Istimewa Yogyakarta.Sampel dalam penelitian ini yaitu Auditor BPK-RI perwakilan Provinsi Daerah Istimewa Yogyakarta sertaBadan Keuangan dan Aset Daerah (BKAD) 4 Kabupaten dan 1 Kota di Daerah Istimewa Yogyakarta. Data dalam penelitian ini merupakan data primer yang diperoleh dengan instrumen berupa kuesioner. Jumlah kuesioner yang dibagikan kepada responden sebanyak 120 kuesioner denganhasil 90 kuesioner dinyatakan sempurna dan dapat diolah. Alat analisis yang digunakan adalah SPSS 22.0.Data diproses dengan menggunakan path analysisyang menunjukanhasil bahwa tingkat keseriusan kecurangan, self efficacydan dukungan organisasi tidak berpengaruh terhadap intensi untuk melakukan tindakan whistleblowingdengan locus of commitmentsebagai variabel intervening. Hasil penelitian ini diharapkandapat menjadi bahan pertimbangan untuk membangun sistem whistleblowingyang lebih efektif khususnya bagi organisasi sektor publik.
\end{abstract}

(C) 2019 RAB. Published by Universitas Muhammadiyah Yogyakarta DOI: $10.18196 / \mathrm{rab} .020120$

\section{PENDAHULUAN}

Perekonomian dunia dewasa ini berkembang menjadi semakin kompleks, begitu pula dengan berbagai praktik kecurangan yang menyelimutinya. Tindak kecurangan baik dari sektor privat maupun sektor publik telah marak terungkap beberapa tahun belakangan ini sehingga menimbulkan perhatian serius dari masyarakat. Khususnya dengan terungkapnya berbagai kecurangan dari sektor publik di Indonesia. Tindak kecurangan yang paling serius dan cukup sensitif di Indonesia adalah korupsi. Seberapapun kecilnya dana yang di korupsi, selalu menimbulkan kerugian. Untuk itu korupsi perlu di berantas. Pemberantasan korupsi walaupun dalam skala kecil, tidak kalah strategisnya dengan pemberantasan korupsi dalam skala besar (Diniastri, 2010). Sebagai langkah awal untuk memberantas korupsi, yaitu dengan terlebih dahulu 
dilakukan pendeteksian. Cara yang paling efektif untuk melakukan pendeteksian terhadap tindak korupsi, salah satunya adalah dengan menerapkan whistleblowing.

Whistleblowing (meniup peluit) adalah suatu tindakan pengungkapan kepada pihak internal (manajemen yang lebih tinggi) atau kepada pihak eksternal yang berwenang dan/atau kepada publik tentang adanya suatu yang dipercaya sebagai perilaku yang tidak etis, tidak bermoral, serta melanggar hukum yang dapat menimbulkan kerugian terhadap pemangku kepentingan maupun organisasi. Pihak yang melakukan pelaporan atas perbuatan tidak etis tersebut dinamakan dengan whistleblower. Menjadi seorang whistleblower bukanlah suatu hal yang mudah. Seseorang yang mengetahui adanya tindak kecurangan dalam organisasi umumnya akan mengalami suatu dilema dalam memutuskan apakah harus mengungkapkan kecurangan tersebut atau tetap membiarkannya tersembunyi.

Mengamati kasus seputar whistleblowing suatu negara, salah satunya adalah dengan mengamati adanya kasus korupsi. Di Indonesia, Pedoman umum whistleblowing system telah resmi diterbitkan pada tahun 2008 oleh Komite Nasional Kebijakan Governance (KNKG). Dorongan diterbitkannya Pedoman ini yaitu dengan adanya penelitian dari Institude of Business Ethics pada tahun 2007 yang menyebutkan bahwa setidaknya satu dari empat orang dalam organisasi mengetahui adanya tindak kecurangan, tetapi sebanyak 52\% dari orang tersebut lebih memilih untuk diam dan tidak melakukan apapun (KNKG, 2008). Hal tersebut dikarenakan kurangnya rasa aman dan jaminan keselamatan sebagai dampak dari whistleblowing system yang belum optimal.

Dalam suatu organisasi, penting untuk dilakukan pemahaman terhadap faktor-faktor yang dapat memengaruhi intensi pegawai dalam melakukan tindakan whistleblowing sehingga dapat dirancang suatu sistem whistleblowing yang lebih efektif. Partisipasi dari whistleblower juga sangatlah penting terhadap efektifitas sistem whistleblowing tersebut. Karena sistem tidak akan berjalan dan bermanfaat untuk kelangsungan kebaikan organisasi jika tidak ada pegawai yang memanfaatkan sistem tersebut untuk melaporkan adanya tindak kecurangan.

Penelitian mengenai intensi untuk melakukan tindakan whistleblowing telah dilakukan oleh beberapa peneliti baik dari dalam maupun luar negeri. Penelitian tersebut umumnya mengambil sampel dari kalangan mahasiswa, auditor internal-eksternal, maupun professional accountant yang berkerja di perusahaan. Beberapa penelitian mengenai intensi mahasiswa untuk melakukan tindakan whistleblowing telah dilakukan oleh Chiu (2003) dan Chinadan (2008) di Amerika (Destirana dan Andri, 2014).

Penelitian ini mengacu pada penelitian Bagustianto dan Nurkholis (2015) yang berjudul "Faktor-Faktor yang Memengaruhi Minat Pegawai Negeri Sipil (PNS) Untuk Melakukan Tindakan Whistleblowing (Studi pada PNS BPK RI)". Perbedaan penelitian ini dengan penelitian tersebut yaitu terletak pada objek penelitian, subjek penelitian dan waktu penelitian. Penelitian ini bertujuan untuk meneliti empat determinan whistleblowing yaitu tingkat keseriusan kecurangan, self efficacy, dukungan organisasi dan locus of commitment sebagai variabel intervening. Subjek penelitian yang diambil dalam penelitian ini lebih luas yaitu menguji faktor-faktor yang memengaruhi intensi Pegawai Negeri Sipil (PNS) dalam melakukan tindakan whistleblowing di Indonesia pada lingkup Badan Pemeriksa Keuangan Republik Indonesia perwakilan Provinsi Daerah Istimewa Yogyakarta dan Pemerintah Kota serta Kabupaten se-Daerah Istimewa Yogyakarta yang sebelumnya hanya dilakukan pada lingkup yang lebih kecil yaitu pada Badan Pemeriksa Keuangan (BPK) saja. Sedangkan waktu penelitian ini dilakukan pada tahun 2018.

\section{TINJAUAN LITERATUR DAN PERUMUSAN HIPOTESIS}

\section{Teori Perilaku Prososial (Prosocial Behavior Theory)}

Teori perilaku prososial adalah teori yang membahas mengenai perilaku anggota organisasi untuk ditujukan kepada individu, kelompok, atau organisasi tempat mereka berinteraksi dan mematuhi peraturan organisasi serta dilakukan dengan intensi meningkatkan kesejahteraan individu, kelompok, atau organisasi tersebut (Brief dan Motowidlo, 1986). 


\section{Teori Perilaku Terencana (Theory of Planned Behavior)}

Teori perilaku terencana merupakan sebuah teori psikologis yang menjelaskan hubungan atara keyakinan dan perilaku yang dikemukakan oleh Icek Ajzen pada tahun 1985. Menurut teori ini, manusia akan bertingkah laku sesuai dengan pertimbangan akal sehat dan mempertimbangkan akibat baik atau buruk yang akan diterima dari tingkah laku tersebut (Azwar, 2009).

\section{Teori Pertukaran Sosial}

Gouldner (1960) menjelaskan teori pertukaran sosial dan norma timbal balik sejalan dengan persepsi dukungan organisasi yang dapat menimbulkan perasaan balas budi seseorang terhadap organisasi dan dapat dikurangi dengan melakukan usaha timbal balik. Dalam teori ini diasumsikan bahwa suatu hubungan hanya terjadi apabila kedua belah pihak dapat memperoleh keuntungan dari hubungan tersebut.

\section{Teori Perilaku Organisasi}

Menurut Thoha (2012), teori perilaku organisasi merupakan suatu studi mengenai aspekaspek perilaku manusia dalam suatu kelompok atau organisasi tertentu yang saling bertimbal balik yaitu pengaruh organisasi terhadap manusia juga pengaruh dari manusia terhadap organisasi tersebut. Perilaku organisasi dapat terbentuk dari sifat individu dalam menghadapi berbagai situasi yang terjadi dalam organisasi.

\section{Whistleblowing}

Whistleblowing (meniup peluit) adalah suatu tindakan pengungkapan kepada pihak internal (manajemen yang lebih tinggi) atau kepada pihak eksternal yang berwenang dan/atau kepada publik tentang adanya suatu yang dipercaya sebagai perilaku yang tidak etis, tidak bermoral, serta melanggar hukum yang dapat menimbulkan kerugian terhadap pemangku kepentingan maupun organisasi.

\section{Tingkat Keseriusan Kecurangan}

Setiap anggota organisasi bisa jadi memiliki persepsi yang berbeda mengenai tingkat keseriusan yang mereka ketahui. Miceli dan Near (1985) menyatakan bahwa dugaan kecurangan akan lebih mungkin untuk diungkapkan oleh anggota organisasi apabila kecurangan tersebut serius. Kecurangan yang lebih serius akan menimbulkan dampak yang lebih besar bagi organisasi jika dibandingkan dengan kecurangan yang kurang serius (Winardi, 2013).

\section{Self Efficacy}

Self efficacy merupakan suatu persepsi, keyakinan diri, kepercayaan akan diri seseorang terhadap kemampuan untuk mengatasi berbagai situasi yang terjadi di sekitarnya yang nantinya akan berpengaruh pula terhadap langkah yang mereka ambil untuk mengatasi berbagai situasi tersebut.

\section{Dukungan Organisasi}

Organisasi yang memiliki persepsi dukungan organisasi yang baik akan menimbulkan perasaan nyaman karyawan dalam setiap keputusan yang diambil salah satunya terkait dengan pelaporan apabila terjadi suatu tindakan yang tidak etis dalam organisasi (Alleyne et al. dalam Saud, 2016). 


\section{Locus of Commitment}

Locus of Commitment merupakan arah kesetiaan seseorang mengenai komitmen mereka apakah lebih berpihak terhadap organisasi atau terhadap rekan kerja yang saling bertentangan satu dengan yang lainnya. Dimana dilema ini akan muncul dalam keadaan dimana salah satu dari kedua pihak tersebut melakukan suatu tindakan yang tidak etis atau melanggar hukum dan moral (Taylor dan Curtis, 2010).

\section{Pengaruh tangkat keseriusan kecurangan terhadap locus of commitment}

Tingkat kecurangan yang lebih serius akan menimbulkan kerugian yang lebih besar, jika dibandingkan dengan tingkat keseriusan kecurangan yang kurang serius (Winardi, 2013). Dengan semakin seriusnya kecurangan yang terjadi maka akan memengaruhi komitmen dari anggota organisasi yang mengetahui adanya tindak kecurangan menuju kearah yang lebih positif yaitu dengan berpihak terhadap organisasi. Hal ini sejalan dengan teori perilaku prososial yang memiliki intensi untuk meningkatkan kesejahteraan individu, kelompok atau organisasi. Dalam kasus ini, seseorang yang mengetahui adanya tindak kecurangan selain untuk menyelamatkan organisasi dari kerugian yang besar tetapi juga menyelamatkan dirinya sendiri karena kerugian dalam organisasi pasti akan berdampak terhadap setiap orang yang bekerja dalam organisasi tersebut.

Dengan demikian penelitian ini akan meneliti kemungkinan keriusan kecurangan yang semakin tinggi akan memiliki dampak yang positif terhadap locus of commitment. Sehingga dapat dirumuskan hipotesis sebagai berikut:

\section{$\boldsymbol{H}_{I} \quad$ : Tingkat keseriusan kecurangan berpengaruh postif terhadap locus of commitment.}

\section{Pengaruh self efficacy terhadap locus of commitment}

Menurut Bandura (1997), self efficacy merupakan suatu keyakinan individu terhadap kemampuan diri mereka dalam menghadapi berbagai situasi dan kondisi tertentu. Dengan demikian semakin tinggi tingkat kepercayaan diri seseorang dalam menghadapi suatu masalah maka akan berpengaruh terhadap arah kesetiaan orang tersebut dalam menghadapi dilema antara komitmen terhadap rekan kerja atau terhadap organisasi tempatnya bekerja. Semakin tinggi tingkat kepercayaan dirinya, maka orang tersebut akan lebih berpihak untuk mengungkapkan kebenaran dengan berpihak kepada organisasi. Sehingga dapat dirumuskan hipotesis sebagai berikut:

\section{$\boldsymbol{H}_{2}$ : Self efficacy berpengaruh positif terhadap locus of commitment.}

\section{Pengaruh dukungan organisasi terhadap locus of commitment}

Gouldner (1960) menyatakan bahwa teori pertukaran sosial dan norma timbal balik sejalan dengan persepsi dukungan organisasi menciptakan perasaan balas budi karyawan terhadap organisasi dan dapat dikurangi dengan usaha yang timbal balik. Persepsi dukungan organisasi yang tinggi dapat menyebabkan perilaku karyawan terhadap kebaikan yang bermanfaat bagi organisasi menjadi semakin tinggi pula. Dengan demikian, persepsi dukungan organisasi yang tinggi akan memengaruhi tingkat komitmen organisasi karyawan, sehingga karyawan akan lebih berkomitmen untuk berkontribusi terhadap organisasi. Maka dari itu penelitian ini akan mengangkat hipotesis sebagai berikut:

$\boldsymbol{H}_{3}$ : Dukungan organisasi berpengaruh positif terhadap locus of commitment. 


\section{Pengaruh tingkat keseriusan kecurangan terhadap intensi untuk melakukan tindakan whistleblowing}

Keseriusan kecurangan dapat didefinisikan sebagai efek yang dapat ditimbulkan dari adanya suatu pelanggaran baik secara finansial maupun non finansial. Miceli dan Near (1985) menyatakan bahwa anggota organisasi yang mengetahui adanya kecurangan akan lebih berpotensi untuk melaporkan kecurangan jika kecurangan tersebut serius. Hal tersebut diatas sejalan dengan teori perilaku prososial yaitu individual anteseden yang meliputi aspek-aspek dalam diri individu dalam memangdang tanggung jawabnya terhadap lingkungan organisasinya, kemampuan individu dalam menginternalisasi standar keadilan dan kemampuan penalaran serta empatinya terhadap lingkungan sekitar. Dengan semakin seriusnya tingkat keseriusan kecurangan yang terjadi, maka individu yang mengetahui adanya tindak kecurangan akan merasa bertanggungjawab untuk melaporkannya mengingat berbagai kerugian yang akan di timbulkan baik bagi organisasi maupun bagi individu secara personal yang bekerja dalam organisasi tersebut. Berdasarkan penjelasan di atas, peneliti mengajukan hipotesis sebagai berikut:

$\boldsymbol{H}_{4}$ : Tingkat keseriusan kecurangan berpengaruh positif terhadap intensi untuk melakukan tindakan whistleblowing.

\section{Pengaruh self efficacy terhadap intensi untuk melakukan tindakan whistleblowing}

Self efficacy memengaruhi cara seseorang dalam menghadapi setiap permasalahan yang terjadi. Semakin tinggi tingkat self efficacy yang dimiliki maka semakin tinggi pula tingkat kepercayaan diri orang tersebut dalam menyelesaikan masalah yang dihadapinya. Teori yang mendukung hipotesis ini adalah teori perilaku terencana yang menjelaskan hubungan antara keyakinan dan perilaku yang dikemukakan oleh Icek Ajzen (1985). Berdasarkan persepsi kontrol perilaku selain faktor eksternal, seseorang akan bertindak sesuai dengan faktor internalnya yaitu kepercayaan diri, keterampilan, kemauan, dan lain sebagainya. Dengan demikian, dapat disimpulkan bahwa seseorang yang memiliki self efficacy yang tinggi akan cenderung untuk lebih berani menungkapkan berbagai jenis kecurangan yang terjadi dalam organisasinya. Maka dari itu, peneliti mengajukan hipotesis sebagai berikut:

\section{$\boldsymbol{H}_{s} \quad$ : Self efficacy berpengaruh positif terhadap intensi untuk melakukan tindakan whistleblowing.}

\section{Pengaruh dukungan organisasi terhadap intensi untuk melakukan tindakan whistleblowing}

Persepsi dukungan organisasi mengarah terhadap kepercayaan seorang karyawan mengenai sejauh mana organisasi menghargai kontribusi yang telah di berikan oleh karyawan dan seberapa tingkat kepedulian organisasi terhadap kesejahteraan karyawannya. Persepsi dukungan organisasi tersebut, apabila tinggi maka akan menghasilkan dampak yang positif bagi keberlangsungan organisasi diantaranya yaitu memengaruhi perilaku karyawan untuk menghasilkan sesuatu yang positif dan bermanfaat bagi organisasi. Berdasarkan teori pertukaran sosial yang mengusung norma timbal balik, tingkat dukungan organisasi yang dirasakan oleh karyawan dapat menjadikan karyawan merasa berkewajiban untuk berkomitmen tidak hanya untuk atasan mereka, tetapi juga berkewajiban untuk terlibat dalam perilaku yang dapat mendukung tercapainya tujuan dari organisasi (Eisenberger et al, 1986). Berdasarkan uraian tersebut, maka peneliti mengajukan hipotesis sebagai berikut: $\boldsymbol{H}_{\sigma} \quad$ : Dukungan organisasi berpengaruh positif terhadap intensi untuk melakukan tindakan
whistleblowing. 


\section{Pengaruh locus of commitment terhadap intensi untuk melakukan tindakan whistleblowing}

Komitmen organisasi secara tidak langsung menjelaskan hubungan atara karyawan dengan organisasi secara aktif. Sesuai dengan teori perilaku organisasi yang mendeterminasi perilaku manusia dalam mencapai tujuan-tujuan organisasi, karyawan yang memiliki komitmen tinggi terhadap organisasi cenderung memiliki keinginan untuk lebih bermanfaat dalam organisasi tempatnya bekerja. Dalam keadaan tertentu, hubungan antara komitmen terhadap organisasi dapat bertentangan dengan komitmen terhadap rekan kerja. Hal ini dapat dijumpai dalam keadaan dimana rekan kerja melakukan suatu tindakan yang tidak etis sehingga memicu konflik berupa dilema antara komitmen organisasi dan komitmen rekan kerja yang saling bertentangan satu sama lain. Oleh karena itu, dalam penelitian ini peneliti ingin menguji bagaimana pengaruh arah kesetiaan seseorang terhadap intensi orang tersebut untuk melakukan tindakan whistleblowing, sehingga peneliti mengajukan hipotesis sebagai berikut:

$\boldsymbol{H}_{7} \quad$ : Locus of commitment berpengaruh positif terhadap intensi untuk melakukan tindakan whistleblowing.

Pengaruh tingkat keseriusan kecurangan, self efficacy dan dukungan perusahaan terhadap intensi untuk melakukan tindakan whistleblowing dengan locus of commitment sebagai variabel intervening.

Pengaruh tingkat keseriusan kecurangan terhadap intensi untuk melakukan tindakan whistleblowing dengan locus of commitment sebagai variabel intervening. Semakin besar dampak kecurangan yang dialami oleh organisasi atau individu yang berada dalam organisasi tersebut, maka menjadi semakin besar pula keinginan dari anggota organisasi yang mengetahui adanya suatu tindakan yang tidak etis untuk melaporkannya (whistleblowing). Akan tetapi, pengaruh tingkat keseriusan kecurangan terhadap intensi seseorang untuk melakukan tindakan whistleblowing juga dipengaruhi secara tidak langsung oleh locus of commitment. Hal ini didukung dengan teori perilaku prososial yaitu individual anteseden yang meliputi aspek dalam diri individu berupa kemampuan individu dalam memangdang tanggung jawabnya terhadap lingkungan sosial, menginternalisasi standar keadilan, serta kemampuan penalaran dan empati terhadap lingkungan sekitar. Berdasarkan uraian di atas, maka dapat diambil hipotesis sebagai berikut:

$\boldsymbol{H}_{s_{a}} \quad$ : Tingkat keseriusan kecurangan berpengaruh positif terhadap intensi untuk melakukan tindakan whistleblowing dengan locus of commitment sebagai variabel intervening.

Pengaruh self efficacy terhadap intensi untuk melakukan tindakan whistleblowing dengan locus of commitment sebagai variabel intervening

Pengaruh self efficacy terhadap intensi seseorang untuk melakukan tindakan whistleblowing juga dipengaruhi pula oleh locus of commitment secara tidak langsung. Locus of commitment akan berpengaruh terhadap arah kesetiaan orang tersebut dalam organisasi. Hipotesis ini didukung oleh teori perilaku terencana dimana teori ini menjelaskan hubungan antara keyakinan dan perilaku. Menurut teori ini, manusia akan bertingkah laku sesuai dengan pertimbangan akal sehat dan mempertimbangkan akibat baik atau buruk yang akan diterima dari perilaku tersebut (Azwar, 2009). Dengan demikian, berdasarkan uraian diatas maka peneliti mengangkat hipotesis sebagai berikut:

$\boldsymbol{H}_{s b} \quad$ :Self efficacy berpengaruh positif terhadap intensi untuk melakukan tindakan whistleblowing dengan locus of commitment sebagai variabel intervening. 
Pengaruh dukungan organisasi terhadap intensi untuk melakukan tindakan whistleblowing dengan locus of commitment sebagai variabel intervening

Salah satu faktor yang mendukung seorang individu untuk melaporkan suatu tindakan tidak etis adalah dukungan dari organisasi itu sendiri (Alleyne et al., 2013). Persepsi dukungan organisasi yang berpengaruh terhadap intensi untuk melakukan tindakan whistleblowing dipengaruhi pula secara tidak langsung oleh locus of commitment, dimana locus of commitment akan memengaruhi tingkat kesetiaan calon whistleblower apakah harus berpihak terhadap organisasi atau berpihak terhadap rekan kerjanya. Berdasarkan teori pertukaran sosial yang dikemukakan oleh Gouldner (1960), persepsi dukungan organisasi akan menciptakan perasaan balas budi karyawan terhadap organisasi dan hal tersebut dapat dikurangi dengan berusaha untuk melakukan manfaat yang timbal balik. Berdasarkan penjelasan tersebut, maka peneliti mengambil hipotesis sebagai berikut:

$\boldsymbol{H}_{s c} \quad$ : Dukungan organisasi berpengaruh positif terhadap intensi untuk melakukan tindakan whistleblowing dengan locus of commitment sebagai variabel intervening.

\section{METODE PENELITIAN}

Objek dalam penelitian ini adalah intensi untuk melakukan tindakan whistleblowing oleh Pegawai Negeri Sipil yang bekerja pada Badan Pemeriksa Keuangan Republik Indonesia dan Pemerintah kota serta kabupaten se-Daerah Istimewa Yogyakarta serta faktor-faktor yang memengaruhi intensi whistleblowing tersebut. Populasi dalam penelitian ini yaitu Pegawai Negeri Sipil di lingkungan Badan Pemeriksa Keuangan Republik Indonesia perwakilan Provinsi Daerah Istimewa Yogyakarta dan Pegawai Negeri Sipil di lingkungan Pemerintah Kota serta Kabupaten seDaerah Istimewa Yogyakarta. Jenis data yang digunakan pada penelitian ini adalah data kuantitatif yaitu data primer. Data primer yaitu data yang diperoleh langsung dengan menyebarkan kuesioner kepada auditor BPK dan pegawai pemerintah daerah kabupaten dan kota di Daerah Istimewa Yogyakarta. Pengambilan sampel dalam penelitian ini menggunakan dua teknik yaitu cluster sampling dan convenience sampling. Metode pengambilan data yang digunakan adalah survey method. Alat pengujian hipotesis $\mathrm{H}_{1}, \mathrm{H}_{2}, \mathrm{H}_{3}, \mathrm{H}_{4}, \mathrm{H}_{5}, \mathrm{H}_{6}, \mathrm{H}_{7}, \mathrm{H}_{\mathrm{s}}, \mathrm{H}_{\mathrm{sb}}$ dan $\mathrm{H}_{8 c}$ yaitu path analysis (analisis jalur) dengan menggunakan program Statistical package for social sciences (SPSS) versi 22.

\section{HASIL DAN PEMBAHASAN}

\section{Uji Koefisien Determinasi (Adjusted R²)}

Tabel 1 Hasil Uji Koefisien Determinasi 1

\begin{tabular}{llll}
\hline Model & R & R Square & Adjusted R Square \\
\hline 1 & $.823^{\mathrm{a}}$ & .677 & .666 \\
a. Predictors: (Constant), DO, TKK, SE & \\
b. Dependent Variable: LC & \\
\hline
\end{tabular}

Sumber: Output SPSS v.22, 2018

Tabel 1 menunjukan besarnya adjusted $\boldsymbol{R}^{2}$ sebesar 0,666, hal ini berarti 66,6\% variabel Locus of Commitment dapat dijelaskan oleh 3 variabel independen Tingkat Keseriusan Kecurangan, Self Efficacy dan Dukungan Organisasi, sedangkan sisanya $(100 \%-66,6 \%=33,4 \%)$ dijelaskan oleh variabel lain diluar model penelitian. 
Tabel 2 Hasil Uji Koefisien Determinasi 2

\begin{tabular}{llll}
\hline Model & R & R Square & Adjusted R Square \\
\hline 1 & $.621^{\text {a }}$ & .386 & .357 \\
a. Predictors: (Constant), LC, TKK, SE, DO & \\
b. Dependent Variable: IW &
\end{tabular}

Sumber: Output SPSS v.22, 2018

Tabel 2 menunjukan besarnya adjusted $R^{2}$ sebesar 0,357, hal ini berarti 35,7\% variabel Intensi untuk Melakukan Tindakan Whistleblowing dapat dijelaskan oleh 4 variabel independen Tingkat Keseriusan Kecurangan, Self Efficacy, Dukungan Organisasi dan Locus of Commitment, sedangkan sisanya $(100 \%-35,7 \%=64,3 \%)$ dijelaskan oleh variabel lain diluar model penelitian.

\section{Analisis Regresi Linier Berganda}

Tabel 3 Hasil Uji Analisis Regresi Linier Berganda 1

\begin{tabular}{lllllll}
\hline \multirow{2}{*}{ Model } & \multicolumn{2}{l}{ Unstandardized Coefficients } & \multicolumn{2}{l}{ Standardized Coefficients } & & Sig. \\
\cline { 2 - 5 } & $\mathrm{B}$ & Std. Error & Beta & & .760 & .449 \\
\hline (Constant) & 4.031 & 5.303 & .067 & 1.067 & .289 \\
TKK & .345 & .323 & .313 & 4.801 & .000 \\
SE & .505 & .105 & .652 & 10.049 & .000 \\
DO & 1.400 & .139 & & & \\
a. Dependent Variable: LC & & &
\end{tabular}

Sumber: Output SPSS, 2018

Berdasarkan tabel 3, diperoleh persamaan sebagai berikut:

$$
\mathbf{L C}=0,067 \mathrm{TKK}+0,313 \mathrm{SE}+0,652 \mathrm{DO}+\varepsilon
$$

Tabel 4 Hasil Uji Analisis Regresi Linier Berganda 2

\begin{tabular}{lllllll}
\hline & \multicolumn{2}{l}{ Unstandardized Coefficients } & \multicolumn{2}{l}{ Standardized Coefficients } & & Sig. \\
\cline { 2 - 5 } Model & $\mathrm{B}$ & Std. Error & Beta & & 4.391 & .000 \\
\hline 1 & (Constant) & 10.870 & 2.475 & .598 & 6.809 & .000 \\
TKK & 1.031 & .151 & -.230 & -2.261 & .026 \\
SE & -.125 & .055 & -.269 & -2.030 & .046 \\
DO & -.194 & .096 & .260 & 1.738 & .086 \\
\multicolumn{2}{l}{ LC } & .087 & .050 & & &
\end{tabular}

Sumber: Output SPSS, 2018

Berdasarkan tabel 4, diperoleh persamaan regresi linier berganda sebagai berikut:

$$
\text { IW }=0,598 \mathrm{TKK}-0,230 \mathrm{SE}-0,269 \mathrm{DO}+0,260 \mathrm{LC}+\boldsymbol{\varepsilon}
$$

Berdasarkan hasil uji analisis regresi linier berganda tersebut diketahui bahwa locus of commitment bukan merupakan variabel intervening yang memediasi tingkat keseriusan kecurangan, self efficacy dan dukungan organisasi terhadap intensi untuk melakukan tindakan whistleblowing karena nilai signifikansi locus of commitment terhadap intensi untuk melakukan tindakan whistleblowing sebesar 0,086 > 0,05 atau tidak signifikan. Sehingga dapat disimpulkan bahwa locus of commitment bukan merupakan variabel intervening yang memediasi tingkat keseriusan kecurangan, self efficacy dan dukungan organisasi terhadap intensi untuk melakukan tindakan whistleblowing. 


\section{Tingkat keseriusan kecurangan terhadap locus of commitment}

Pengujian hipotesis pertama melalui analisis statistik menunjukan bahwa tingkat keseriusan kecurangan tidak berpengaruh terhadap locus of commitment. Ditolaknya hipotesis ini sejalan dengan teori perilaku prososial yang memiliki intensi untuk meningkatkan kesejahteraan individu, kelompok, atau organisasi. Dalam kasus ini, seseorang yang mengetahui adanya tindak kecurangan, selain untuk menyelamatkan organisasi tetapi juga menyelamatkan dirinya sendiri karena kerugian yang terjadi dalam organisasi pasti akan berdampak pada setiap orang yang bekerja dalam organisasi. Kecurangan dalam skala rendah apabila dibiarkan maka semakin lama akan menimbulkan kerugian yang besar juga sehingga pemberantasan kecurangan walaupun dalam skala rendah sama strategisnya dengan pemberantasan kecurangan dalam skala tinggi. Hal tersebut diatas akan mendorong whistleblower untuk berpihak terhadap organisasi yaitu melakukan tindakan whistleblowing tanpa memandang tinggi atau rendahnya tingkat suatu kecurangan.

\section{Seff efficacy terhadap locus of commitment}

Pengujian hipotesis kedua melalui analisis statistik menunjukan bahwa self efficacy berpengaruh terhadap locus of commitment. Hasil tersebut didukung dengan teori perilaku terencana yang dikemukakan oleh Icek Ajzen (1985), dimana menurut teori ini individu akan berperilaku sesuai dengan akal sehat dan mempertimbangkan akibat baik atau buruk yang akan diterimanya. Pegawai Negeri Sipil (PNS) yang mengetahui adanya suatu tindak kecurangan akan lebih berpihak terhadap organisasi tempatnya bekerja. Karena semakin tinggi tingkat kepercayaan diri seseorang dalam menghadapi suatu masalah maka akan berpengaruh terhadap arah kesetiaan orang tersebut dalam menghadapi dilema antara komitmen terhadap rekan kerja atau kepada organisasi tempatnya bekerja. Semakin tinggi tingkat kepercayaan dirinya, maka ia akan lebih memilih untuk memihak kepada pihak yang benar yaitu organisasi yang akan dirugikan atas tindak kecurangan yang terjadi.

\section{Dukungan organisasi terhadap locus of commitment}

Pengujian hipotesis ketiga melalui analisis statistik menunjukan bahwa dukungan organisasi berpengaruh terhadap locus of commitment. Menurut Gouldner (1960), teori pertukaran sosial dan norma timbal balik sejalan dengan persepsi dukungan organisasi yaitu menciptakan perasaan balas budi karyawan terhadap organisai dan dapat dikurangi dengan usaha timbal balik. Persepsi dukungan organisasi yang tinggi mengarahkan perilaku karyawan untuk memberikan kebaikan yang bermanfaat bagi organisasi. Dengan demikian, semakin tinggi dukungan organisasi yang diterima akan memengaruhi tingkat komitmen karyawan yaitu untuk lebih berkontribusi terhadap organisasi, salah satunya adalah dengan cara memihak kepada organisasi apabila terjadi suatu tindakan tidak etis yang dilakukan oleh rekan kerjanya serta dapat menimbulkan kerugian bagi organisasi.

\section{Tingkat keseriusan kecurangan terhadap intensi untuk melakukan tindakan whistleblowing}

Pengujian hipotesis keempat melalui analisis statistik menunjukan bahwa tingkat keseriusan kecurangan berpengaruh terhadap intensi seseorang untuk melakukan tindakan whistleblowing. Hasil penelitian ini mengonfirmasi teori perilaku prososial yaitu individual anteseden, yang meliputi aspek-aspek dalam diri individu dalam memandang tanggung jawabnya terhadap lingkungan organisasi, kemampuan individu dalam menginternalisasi standar keadilan dan kemampuan penalaran, serta empati terhadap lingkungan sekitar. Dengan semakin tinggi tingkat keseriusan kecurangan yang terjadi, maka individu yang mengetahui adanya suatu tindak kecurangan akan merasa bertanggungjawab untuk melaporkan kecurangan tersebut. Mengingat berbagai kerugian yang akan di timbulkan baik bagi organisasi maupun bagi individu yang bekerja dalam organisasi termasuk dirinya yang mengetahui adanya suatu tindak kecurangan itu sendiri. 


\section{Self efficacy terhadap intensi untuk melakukan tindakan whistleblowing}

Pengujian hipotesis kelima melalui analisis statistik menunjukan bahwa self efficacy berpengaruh negatif terhadap intensi seseorang untuk melakukan tindakan whistleblowing. Menurut peneliti, penolakan hipotesis ini disebabkan karena dengan semakin tingginya tingkat kepercayaan diri responden (Pegawai Negeri Sipil) terhadap kemampuannya dalam menghadapi suatu masalah, akan memengaruhi cara responden tersebut mengatasi masalah yang sedang dihadapinya seperti yang tertuang dalam teori perilaku terencana yang menjelaskan antara keyakinan dan perilaku. Seperti yang kita semua ketahui bahwa metode untuk mendeteksi dan memberantas kecurangan dalam suatu organisasi tidak hanya terbatas pada whistleblowing system saja tetapi masih terdapat metode yang lainnya seperti Internal controlling system, internal audit maupun eksternal audit (Sweeney, 2008). Menurut pandangan peneliti, responden dalam penelitian ini merasa yakin akan kemampuannya mengendalikan kecurangan dengan menerapkan metode pengendalian yang lain sehingga tidak memilih whistleblowing system untuk memerangi kecurangan yang terjadi dalam organisasinya.

\section{Dukungan organisasi terhadap intensi untuk melakukan tindakan whistleblowing}

Pengujian hipotesis keenam melalui analisis statistik menunjukan bahwa dukungan organisasi memiliki pengaruh negatif terhadap intensi untuk melakukan tindakan whistleblowing. Menurut peneliti, ditolaknya hipotesis ini mengindikasikan bahwa organisasi tempat responden bekerja telah menerapkan sistim yang baik terhadap pencegahan dan pengendalian kecurangan. Ditolaknya hipotesis ini juga didukung oleh teori perilaku prososial yaitu kontekstual anteseden yang meliputi aspek-aspek dari organisasi dan lingkungan organisasi yaitu peraturan, kelompok, panutan, norma, iklim organisasi, tipe kepemimpinan, komitmen terhadap organisasi, tekanan, dan hal-hal lainnya yang memengaruhi tingkat kepuasan seseorang (Brief dan Motowidlo, 1986).

Pada hipotesis sebelumnya peneliti telah membahas bahwa metode untuk mencegah dan memberantas kecurangan tidak hanya terbatas pada whistleblowing system saja, tetapi masih terdapat metode yang lainnya seperti Internal controlling system, internal audit maupun eksternal audit (Sweeney, 2008). Oleh karena organisasi tempat responden bekerja telah menerapkan sistem yang baik terhadap pencegahan dan pengendalian kecurangan, maka responden tidak menerapkan whistleblowing sytem yang dimana menjadi seorang whistleblower memang bukan merupakan suatu hal yang mudah. Terdapat ancaman baik fisik maupun psikis dan secara langsung maupun tidak langsung yang dapat diterima oleh whistleblower. Melakukan whistleblowing memang merupakan suatu tindakan yang cukup berisiko dan menimbulkan dilema bagi whistleblower itu sendiri.

\section{Locus of commitment terhadap intensi untuk melakukan tindakan whistleblowing}

Pengujian hipotesis ketujuh melalui analisis statistik menunjukan bahwa locus of commitment tidak berpengaruh terhadap intensi untuk melakukan tindakan whistleblowing. Tidak adanya pengaruh yang signifikan dari locus of commitment terhadap intensi untuk melakukan tindakan whistleblowing dapat dikarenakan adanya faktor yang memengaruhi kepuasan kerja responden yang dapat berasal dari rekan kerja atau pimpinan organisasi secara umum (Kreshastuti, 2014). Menurut Misener et al. (1996) aspek-aspek kepuasan kerja itu sendiri dapat berhubungan dengan gaji, keuntungan, promosi, kondisi kerja dan lain sebagainya. Dalam theory of planned behavior, seperti yang dijelaskan dalam konsep norma subjektifnya, persepsi atau pandangan seseorang terhadap suatu kepercayaan orang lain akan memengaruhi niat untuk melakukan atau tidak melakukan suatu perilaku yang sedang dipertimbangkan. Demikian juga yang berkaitan dengan komitmen yang dimiliki responden dalam penelitian ini dimana responden sulit menentukan untuk berkomitmen terhadap rekan kerja atau kepada organisasi. 
Tingkat keseriusan kecurangan, self efficacy dan dukungan organisasi terhadap intensi untuk melakukan tindakan whistleblowing dengan locus of commitment sebagai variabel intervening

a. Tingkat keseriusan kecurangan terhadap intensi untuk melakukan tindakan whistleblowing dengan locus of commitment sebagai variabel intervening

Berdasarkan hasil pengujian, diketahui bahwa locus of commitment bukan merupakan variabel intervening antara tingkat keseriusan kecurangan terhadap intensi untuk melakukan tindakan whistleblowing. Hal ini dikarenakan meskipun tingkat keseriusan kecurangan berpengaruh terhadap intensi untuk melakukan tindakan whistleblowing, tetapi tingkat keseriusan kecurangan tidak memiliki pengaruh yang signifikan terhadap locus of commitment begitu juga locus of commitment tidak memiliki pengaruh yang signifikan terhadap intensi untuk melakukan tindakan whistleblowing.

b. Self efficacy terhadap intensi untuk melakukan tindakan whistleblowing dengan locus of commitment sebagai variabel intervening

Berdasarkan hasil pengujian, diketahui bahwa locus of commitment bukan merupakan variabel intervening antara self efficacy terhadap intensi untuk melakukan tindakan whistleblowing. Hal ini dikarenakan self efficacy walaupun memiliki hubungan yang signifikan tetapi memiliki pengaruh negatif terhadap intensi untuk melakukan tindakan whistleblowing dan locus of commitment tidak memiliki hubungan yang signifikan terhadap intensi untuk melakukan tindakan whistleblowing, meskipun self efficacy memiliki pengaruh yang signifikan terhadap locus of commitment.

c. Pengaruh dukungan organisasi terhadap intensi untuk melakukan tindakan whistleblowing dengan locus of commitment sebagai variabel intervening

Berdasarkan hasil pengujian, diketahui bahwa locus of commitment bukan merupakan variabel intervening antara dukungan organisasi terhadap intensi untuk melakukan tindakan whistleblowing. Hal ini dikarenakan dukungan organisasi walaupun memiliki hubungan yang signifikan tetapi memiliki pengaruh negatif terhadap intensi untuk melakukan tindakan whistleblowing dan locus of commitment tidak memiliki hubungan yang signifikan terhadap intensi untuk melakukan tindakan whistleblowing, meskipun dukungan organisasi memiliki pengaruh yang signifikan terhadap locus of commitment.

\section{KETERBATASAN PENELITIAN}

Beberapa keterbatasan dalam penelitian ini yang dapat diperbaiki dalam penelitian selanjutnya responden dalam penelitian ini hanyalah Pegawai Negeri Sipil di lingkungan Badan Pemeriksa Keuangan Republik Indonesia perwakilan Provinsi Daerah Istimewa Yogyakarta dan Pegawai Negeri Sipil di lingkungan Pemerintah Kota serta Kabupaten se-Daerah Istimewa Yogyakarta sehingga hasil penelitian belum tentu sesuai untuk digeneralisasi/digunakan pada organisasi lain. Penelitian ini tidak spesifik mendefinisikan intensi whistleblowingpada saluran atau bentuk whistleblowing tertentu, sehingga generalisasi model regresi penelitian ini terbatas pada definisi whistleblowingsecara umum. Metode pengumpulan data dalam penelitian ini adalah metode survey dengan menggunakan kuesioner sehingga jawaban dari responden tidak dapat dikontrol secara pasti apakah jawaban tersebut jujur atau tidak. Pendistribusian kuesioner yaitu saat responden sedang bekerja sehingga tingkat pengembalian kuesioner hanya 84,16\%. 


\section{KESIMPULAN}

Dalam penelitian ini dapat disimpulkan bahwa tingkat keseriusan kecurangan tidak berpengaruh terhadap locus of commitment. Self efficacy berpengaruh positif terhadap locus of commitment. Dukungan organisasi berpengaruh positif terhadap locus of commitment. Tingkat keseriusan kecurangan berpengaruh positif terhadap intensi untuk melakukan tindakan whistleblowing. Self efficacy berpengaruh negatif terhadap intensi untuk melakukan tindakan whistleblowing. Dukungan organisasi berpengaruh negatif terhadap intensi untuk melakukan tindakan whistleblowing. Locus of commitment tidak berpengaruh terhadap intensi untuk melakukan tindakan whistleblowing. Locus of commitment bukan merupakan variabel intervening yang memediasi tingkat keseriusan kecurangan terhadap intensi untuk melakukan tindakan whistleblowing. Locus of commitment bukan merupakan variabel intervening yang memediasi self efficacy terhadap intensi untuk melakukan tindakan whistleblowing. Locus of commitment bukan merupakan variabel intervening yang memediasi dukungan organisasi terhadap intensi untuk melakukan tindakan whistleblowing.

Saran dalam penelitian ini diharapkan penelitian selanjutnya diharapkan menggunakan metode penelitian yang berbeda, seperti metode wawancara langsung kepada responden agar mencerminkan jawaban atas kondisi sebenarnya. Penelitian selanjutnya diharapkan dapat memperluas obyek penelitian terhadap organisasi lain yang menerapkan whistleblowing system,misalnya kementerian Keuangan, kementerian Agama atau dilakukan di perusahaan BUMN seperti PT. PLN Persero. Penelitian selanjutnya diharapkan dapat menambah atau menggunakan variabel lain yang mungkin dapat memengaruhi intensi untuk melakukan tindakan whistleblowing.

\section{DAFTAR PUSTAKA}

Ab Ghani, N. (2013). Predicting Whistle-Blowing Intention in Malaysia: Evidence from Manufacturing Companies. Dissertation (PhD). Curtin University, Curtin Graduate School of Business.

Agoes, S., \& Ardana, I. C. (2011). Etika Bisnis dan Profesi: Tantangan Membangun Manusia Seutuhnya. Edisi Revisi. Cetakan Kedua. Jakarta: Salemba Empat.

Ajzen, I. (1991). The Theory of Planned Behavior. "Organizational Behavior and Human Decision Processes. 50, 179-211.

Aliyah, S. (2015). Analisis Faktor-Faktor yang Mempengaruhi Minat Pegawai dalam Melakukan Tindakan Whistleblowing. Jurnal Dinamika Ekonomi dan Bisnis. 12 (2), 173-189.

Alleyne, P., Hudaib, M., \& Pike, R. (2013). Towards a Conceptual Model of Whislte-blowing Intention Among External Auditors. The British Accounting Review, 45: 10-23.

Bagustianto, R., \& Nurkholis. (2015). Faktor-Faktor yang Mempengaruhi Minat Pegawai Negeri Sipil (PNS) Untuk Melakukan Tindakan Whistleblowing. Simposium Nasional Akuntansi XVIII, Medan, 16-19 September.

Brief, A. P. \& Motowidlo, S. J. (1986). Prosocial Organizational Behaviors. Academy of Management Review. 11 (4), 710-725.

Cullen, J. B., Parboteeah, K. P., \& Victor, B. (2003). The effects of ethical climates on organizational commitment: A two-study analysis. Journal of Business Ethics, 46(2), 127-141.

Dozier, J. B., \& Miceli, M. P. (1985). Potential predictors of whistle-blowing: A prosocial behavior perspective. Academy of Management Review, 10 (4), 823-836.

Ghozali, I. (2015). Aplikasi Analisis Multivariance dan Program SPSS. Semarang: Badan Penerbit Universitas Diponorogo.

Kaplan, S. E. \& Whitecotton, S. M. (2001). An Examination of Auditor's Reporting Intentions When Another Auditor is Offered Client Employment. A Journal of Practice and Theory. 20 (1), 45-63.

KNKG. (2008). Pedoman Sistem Pelaporan Pelanggaran - SPP (Whistleblowing System - WBS). Jakarta: KNKG. 
Kreshastuti, D. K. (2014). Analisis Faktor-Faktor yang Mempengaruhi Intensi Auditor Untuk Melakukan Tindakan Whistleblowing (Studi Empiris Pada Kantor Akuntan Publik Di Semarang). Skripsi. FEB, Universitas Diponegoro.

Nazarudin, I., \& Basuki, A. T. (2016). Analisis Statistik dengan SPSS. Yogyakartta: Danisa Media.

Saud, I. M. (2016). Pengaruh Sikap dan Persepsi Kontrol Perilaku Terhadap Niat Whistleblowing Internal-Eksternal dengan Persepsi Dukungan Organisasi Sebagai Variabel Pemoderasi. Jurnal Akuntansi dan Investasi, 17(2), 209-219.

Sekaran, U., \& Bougie, R. (2013). Research Methods for Business: A Skill Building Approach Sixth Edition. Chichester: Wiley.

Semendawai, A.H., F. Santoso, W. Wagiman, B.I. Omas, Susilaningtyas, \& S.M. Wiryawan. (2011). Memahami Whistleblower. Jakarta: Lembaga Perlindungan Saksi dan Korban (LPSK).

Septianti, W. (2013). Pengaruh Faktor Organisasional, Individual, Situasional, dan Demografis Terhadap Niat Melakukan Whistleblowing Internal. Simposium Nasional Akuntansi XVI, Manado, 25-28 September.

Setyawati, I., Ardiyani, K., \& Sutrisno, C. R. (2015). Faktor-Faktor Yang Mempengaruhi Niat Untuk Melakukan Whistleblowing Internal. Jurnal Ekonomi dan Bisnis. 17, 22-33.

Sugiyono. (2010). Metode Penelitian Bisnis. Cetakan ke-15. Bandung: Alfabeta.

Sweeney, P . (2008). Hotlines Helpful for Blowing The Whistle. Financial Executive. 24 (4), 28-31. 